Oxford Art Journal Advance Access published June 16, 2016

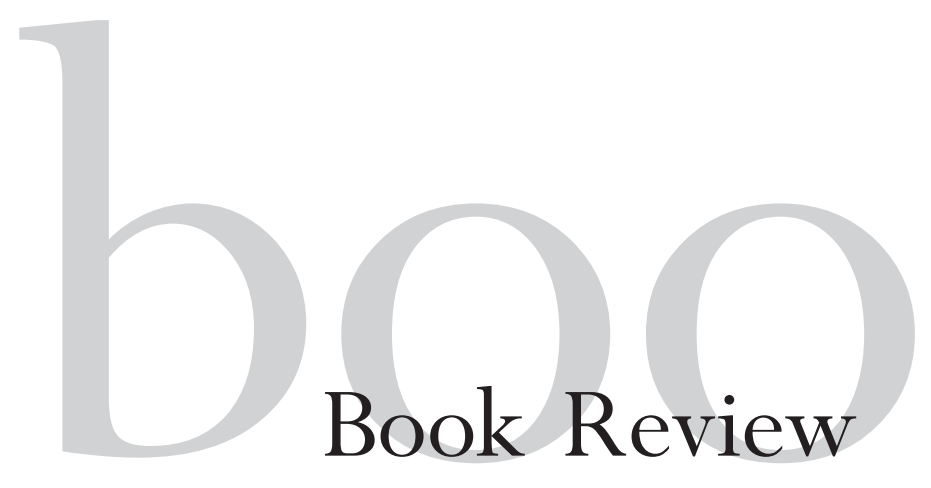

Paul Stephenson 


\section{Byzantine Icons and Things}

\section{Paul Stephenson}

Paroma Chatterjee, The Living Icon in Byzantium and Italy: The Vita Image, Eleventh to Thirteenth Centuries (Cambridge: Cambridge University Press, 2014), 16 colour and 34 b\&w illns, 297 pp., ISBN 9781107034969, hardcover $£ 64.99$

Glenn Peers, ed., Byzantine Things in the World (Houston, Texas: The Menil Collection, 2013; distributed by Yale University Press), 100 colour illns, 192 pp., ISBN 9780300191783 , hardcover $\$ 45$

Bissera V. Pentcheva, The Sensual Icon: Space, Ritual and the Senses in Byzantium (State College, PA: Penn State University Press, 2010), 72 colour and 19 b\&w illns, 320 pp., ISBN 9780271035833 , paperback $\$ 44.95$

'The very fact that the Byzantines saw their art as realistic, employed this concept as a criterion of excellence, and used lifelikeness as a term of praise for achievements they admired suggests the utility of separating their responses from our own.' This judgment of Anthony Cutler would surely seem apposite to most today who look upon Byzantine art. ${ }^{1}$ The fissure between modern and medieval viewer is widened by the well-known fact that the Byzantines did not have a word for art, or at least did not use a specific term in the manner that we may choose (or not) to differentiate the work of a 'maker', to use Cutler's word, from an artist. Byzantinists cannot identify these makers and now most do not wish to do so, consciously differentiating themselves from art historians of more recent periods who may consider it essential to know the intimate details of an artist's life to understand what he or she has made. An art history without artists requires a greater focus on what has been made and how it has been received and understood, both by those for whom it was made and all those who have looked upon it since. It is partly for this reason that the rise of material culture studies has been welcomed by Byzantinists, who appreciate its focus on the physical remains of past cultures and the relationships between people and their things. We now read frequently of the tactility of Byzantine art, its engagement of all five physical senses and, as importantly, of its numinous qualities, which engaged the intellect, as one might engage with the divine only noetically. The staple of Byzantine art history, the icon, was and is a medium through which one might engage the divine. It was not the only vehicle, of course, but it was among the most accessible and has occasioned the most comment. The icon is richly sensual, made to be stroked and kissed, for light to shine across or through, to cast shadows and be engulfed in scents and smells, to be enlivened by those whose living breath touches it.

This would appear to be a pedestrian point of departure for Bissera Pentcheva, whose strikingly original insights into Byzantine aesthetic theory have been published in several important papers, both before and since the appearance of her second monograph, The Sensual Icon. ${ }^{2}$ Pentcheva's preferred direction is away from 'lifelikeness' towards the 'living icon', an image that 'was literally 'in-spirited' (empsychos, empnous, from pneo and pneuma, 'to breathe and breath'), receiving human breath and responding with a spectacle of shimmer and glimmer' (p. 122). Her works trace the philosophical and sensual emergence of the living image, the eikon, no longer understood as the flat painted panel of the sixth to ninth centuries, nor only as the metal bas-relief icon that dominated in eleventh-century Constantinople, but rather as the ideas that shaped both. The triumph of low relief was ephemeral, as a new iconoclasm of the first decade of Komnenian rule (CE 1081-1204) destroyed icons by melting them down, often using the metal to pay soldiers. From this destruction emerged a new, composite interpretation of eikon, a painted panel with metal revetments.

Paroma Chatterjee takes Pentcheva's definition of the 'living icon' as a stepping-off point in her important new reflection on the vita image, a type that juxtaposes a central icon with framing narrative scenes, and generally painted rather than metal revetment, thus engaging each viewer more fully in the inherent dialogue between centre and frame. As Chatterjee says, 'the beholder of the saint's image (and visions, relics, and dreams) was not expected to remain a passive recipient') (p. 11). Chatterjee's subject is not the maker, whose role was to transmit not create, but the saint, a person with the capacity to become a living image, an icon. As she notes, saints appeared to Byzantines in order to validate icons, not vice versa. The vita icon 'aimed to remind viewers of the tremendous ontological possibilities intrinsic to the very definition of a saint' (p. 215). Chatterjee is also a sensitive and subtle reader of texts. For example, she offers a sophisticated analysis of a passage in the Life of St Nikon, which exposes the tensions between text and image, vision, and representation. These tensions are shown to have survived in the Byzantine understandings of the relationship between a holy presence and its portrayal, even after the matter was supposedly resolved by the formal ending of iconoclasm in CE 843. Perhaps the greatest contribution Chatterjee makes to the discussion of Byzantine sanctity and art is in aiding a better appreciation of complexity. There are no neat answers in her book, which looks in detail at Italy as well as Byzantium, offering compelling insights into parallel developments of the vita icon.

Curators today generally encourage viewers to think with them about the things they have curated, but in a museum or gallery it is possible to engage with the icon through only one sense, sight. Even those who wish to highlight tactility in exhibitions admit defeat. ${ }^{3}$ Kissing and stroking icons is discouraged by those who believe devotional media should be treated in exactly this way, and who embrace the idea that a museum might recreate a devotional space, through appropriate lighting and chanting, and even scenting. Mount Sinai icons have appeared in several recent large exhibitions, having travelled to museums placed in cases within cases, and unpacked and installed in a manner that minimised their contact with the profane, including the hands of curators and the air of New York City and Los Angeles, and certainly the fingers and lips of museum visitors. Monks travelled with the 
icons and remained with them throughout their stays in New York City and Los Angeles, during the Met's blockbuster Byzantine exhibits in 1997 and 2004, and the Getty's 20062007 exhibition Holy Image, Hallowed Ground: Icons from Sinai. ${ }^{4}$

The Byzantines understood that made things might enjoy a peculiar relationship with the numinous or might be filled with divine energy. Few of us find it strange that, when we touch a metal object, e.g. a small copper jug that has been left outside on a summer's day, we find it hot. We understand that the object itself has not generated the heat, but that it has been heated by the sun, and therefore that it is the sun's heat that we feel emanating from it. If one believes that Christ is the true sun, then one understands that matter can be penetrated similarly by divine energy, and that things can transmit that energy to us through our senses. Let us imagine we have gone for a walk on a warm afternoon and forgotten to close our satchel. Light waves released by the sun allow us to see a small copper jug inside, within which our drinking water is now unpleasantly warm, due to the sun's heat rays and the fact that copper conducts heat and energy especially well. The Byzantines understood radiation as we do, but they understood light rays rather differently. Looking at a metal jug, according to the theory of intromission (Democritus, Epicurus), we absorb the atoms or energy that it emits (Plato identified the energy emitted as light rays). If one rejects this premise, preferring the theory of extramission (Euclid, Ptolemy), then the eye emitted energy (pneuma, Galen's term before it was Pentcheva's), which bouncing off the thing returned to the eye. In either case it is energy which passed through the eye to imprint the jug's form in the viewer's mind. In both theories, the eye engages with the thing seen, the jug, and perceives it by sharing its energy, or rather by receiving part of its matter that has been energised by the divine. ${ }^{5}$

Many things absorb the sun's energy, but some store and conduct it better than others. So it is with divine energy, which some things by their nature, by contact or proximity or by how

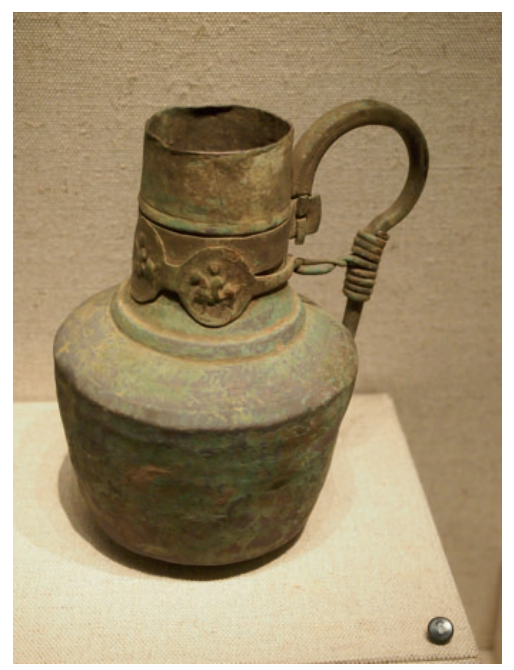

Fig. 1. Copper 'pilgrim jug', sixth or seventh century CE, Walters Art Museum, Baltimore, MD, 53.155, museum purchase, 1991. Photograph: Paul Stephenson. they are fashioned, are able to store and conduct better than others. Pilgrim tokens are especially effective at storing and radiating grace, for they may be fashioned from the soil on which a holy athlete once engaged in spiritual combat with the Devil and his demons. Ampullae, pilgrim flasks, improved upon tokens by containing and preserving holy fluid, e.g. sweat or ooze from a tomb, or water blessed by contact with the saint's tomb, or oil from a jug near a tomb. Water and oil were brought by pilgrims who visited the tomb of St Menas at Abu Mena in Egypt, whence came examples of pilgrim tokens and flasks that can today is to be found in the Walters Art Museum in Baltimore, Maryland, alongside a small copper jug (Fig. 1). Like the ampullae, this jug could contain and preserve a liquid. Today it does not have lid, but a similar jug in the Metropolitan Museum of Art shows that the liquid contained within it would have been prevented from spilling by the insertion of a stopper, attached by a chain to the jug's handle. Of equal practical value is the band around the neck of the jug, which features three tokens of mounted figures, 'holy riders', who would have protected the water not from spilling but from becoming polluted. The jug was permeated by divine energy, by grace, but in placing specific images on its neck we have sought to direct that energy to one purpose.

Pilgrims frequently brought ampullae or jugs as blessings, eulogia, from their destination to protect them as they travelled home. Not all travelers in the late antique and medieval eastern Mediterranean were pilgrims sensu stricto. But pilgrims can be expected to have a feeling for divine energy, so let us imagine the owner of the jug was indeed a pilgrim in and through his world of things absorbing, storing, and radiating grace. Let us explore a proposition: in this world, a Byzantine world, our pilgrim, the subject of this sentence, did not look at and touch his jug, the object of this sentence, in his open satchel and wonder whether his water was too hot to drink. To quote Glenn Peers, 'rather than continue to support this anachronistic imposition of Cartesian civil order [we should argue] for the empathic and heuristic adoption of the relational, animist worldview of Byzantines'. 6 When we write 'the pilgrim (subject) looks at his jug (object)', Peers might observe that we misunderstand the relation between 'dividuals' and deny the jug full subjecthood with full rights of relation and participation.

This formulation may appear designed to repel those who are not engaged in sophisticated scholarship from contemplating the jug and the person who once drank from it. But this is not Peers' intention; quite the opposite is the case. Peer's exploration in dividuation was preparatory work for an exhibition intended to engage a far wider audience, and to present to them Byzantine material culture, Byzantine Things in the World, in a manner that hints at connections the Byzantines may themselves have made. Byzantine things were juxtaposed with, placed in dialogue with modern things, 'likeminded things', so that they may, albeit incompletely, reveal their agency. In Peers' view, “'Art” is a death certificate for Byzantine material culture, because it suppresses all the living, active aspects of these historical things'. ${ }^{7}$ Therefore, if the 'paradoxical process of giving back thingness is difficult, impossible fully ... perhaps eliminating some of the art from 
the thing is a useful strategy, at least as a starting point'. 8 If, as Peers acknowledges, it is impossible fully to recover a Byzantine world of things, his exhibition and its catalogue prove that it is possible to look with fresh eyes at the remains of Byzantium, to engage with Byzantine things in our world alongside other things from other worlds, all drawn from the Menil Collection in Houston, Texas. These include a boli power object from Mali held to exude a 'thick flow of energy known as nyama. . . an animating force, charging people, the landscape, and objects with life'. ${ }^{9}$ This approach to the presentation of the remains of Byzantium is immediately appealing. ${ }^{10}$ In placing emphasis on interaction with and by things it engages more fully the humanity of Byzantines, and invites the viewer to contemplate the similarities and differences between Byzantium and other human societies. This may be contrasted with methods for engaging audiences at recent blockbuster exhibitions of Byzantine art, including ethnic marketing that invited engagement of Greeks, Bulgarians, Russians, others, with 'their' pasts. ${ }^{11}$

Peers' reflections on animate, active, engaging things are substantial because they, like Pentcheva's and Chatterjee's, have both a solid empirical foundation and an established theoretical context. The empirical foundation is provided by the many Byzantine texts that recount tales of wondrous things 'thinging the world'. Admittedly, most of these texts concern icons, things that were fashioned as divine images, or which had divine images painted or impressed upon them. Peers' reflections on icons and things, and on icons as things, also have a solid theoretical basis, allowing us to return to jugs, upon which Martin Heidegger reflected in his essay 'The Thing (Das Ding, 1950)'.12 Heidegger observed that things exist independently of our comprehension of them, even if we have manufactured them, and therefore we cannot fully comprehend them. The jug is not an object, although we objectify that part of it that we comprehend when we look at it. Free of our comprehension, by its unmediated presence, nature, and actions, the jug-thing 'things'. Heidegger's ontological reflections on thingliness have been useful in a number of fields, e.g. ecology, where theorists have developed a biocentric critique of anthropocentrism attitudes towards nature and the relationship between man and the natural environment. Certainly, as Heidegger observed in his earlier reflections on things, "the stone in the road is a thing, as is the clod of earth in the field. A jug is a thing, as is the well beside the road'. ${ }^{13}$ One might observe that there are differences between things that exist in the natural world - a stone, a clod of earth - and made things, such as a road and a jug. It was with made things that Heidegger was mostly concerned in this earlier essay, on 'The origin of the work of art' (1935-1937).

The discussion of 'things' has a long history, pre-dating even Heidegger's initial interest in 1935, and it has informed literature ever since, e.g. Vladimir Nabokov's Transparent Things, where on the first page we read: 'When we concentrate on a material object, whatever its situation, the very act of attention may lead to our involuntarily sinking into the history of that object. Novices must learn to skim over matter if they want matter to stay at the exact level of the moment. Transparent things, through which the past shines!' ${ }^{14}$ Learning to skim rather than sink has been popular in art historical scholarship for decades, although Bill Brown, a leading voice in 'thing theory', reminds us that to consider the very recent engagement with things by Byzantine art historians as belated is only to acknowledge that 'the academic psyche has internalised the fashion system (a system meant to accelerate the obsolescence of things)'. ${ }^{15}$

doi:10.1093/oxartj/kcw003

\section{Notes}

1. Anthony Cutler, 'Makers and Users', in Liz James (ed.), A Companion to Byzantium, (Oxford and Malden, MA: Wiley-Blackwell, 2010), pp. 301-12, at p. 307.

2. Bissera V. Pentcheva, Icons and Power. The Mother of God in Byzantium (University Park, PA: The Pennsylvania State University Press, 2006); 'The Performative Icon', The Art Bulletin, vol. 88, no. 4, 2006, pp. 631-55; 'What is a Byzantine Icon? Constantinople versus Sinai', in Paul Stephenson (ed.), The Byzantine World, (London and New York: Routledge, 2010), pp. 265-83; 'The Aesthetics of Landscape and Icon at Sinai', RES. Anthropology and Aesthetics, no. 6566, 2015, pp. 195-211.

3. Glenn Peers, 'We Have Never Been Byzantine: On Analogy', in Roland Betancourt and Maria Taroutina (eds), Byzantium/Modernism: The Byzantine as Method in Modernity, (Leiden: Brill, 2015), pp. 349-60, at pp. 356-7, observing 'perhaps the sensual museum - aside from children's museums - is simply impossible for us...'.

4. Jori Finkel, 'After 15 Centuries, St. Peter Finally Leaves Home', New York Times, http: / /query.nytimes.com/gst/fullpage.html?res=9907EED6113FF931A2 5752C1A9609C8B63, 12 November 2006.

5. 'The physical sense of sight ... was a form of physical contact between the viewer and the object', Georgia Frank once wrote in an often-cited paper on the Pilgrim's gaze: Georgia Frank, 'The Pilgrim's Gaze in the Age before Icons, in Robert S. Nelson (ed.), Visuality Before and Beyond the Renaissance, Cambridge Studies in New Art History and Criticism; (Cambridge: Cambridge University Press, 2000), pp. 98-115, at p. 108.

6. Glenn Peers, 'Real Living Painting: Quasi-Objects and Dividuation in the Byzantine World', Religion and the Arts, vol. 16, 2012, pp. 433-60, at p. 434

7. Glenn Peers, 'Introduction', in Byzantine Things in the World, pp. 21-35, at p. 28.

8. Glenn Peers, 'Byzantine Things in the World', in Byzantine Things in the World, pp. 38-85, at p. 48 .

9. Susan Sutton, 'Resistant Surfaces', in Byzantine Things in the World, pp. 14051 , at p. 141. It is also possible to reflect upon what we mean when we speak of a Byzantine world.

10. Charles Barber, 'Thingliness', in Byzantine Things in the World, pp. 98-107, offers reflections on jugs and ampullae.

11. Isabel Kimmelfield, 'Exhibiting Byzantium: Three Case Studies In the Display and Reception of Byzantine Art', in Ingela Nilsson and Paul Stephenson (eds), Wanted: Byzantium. The Desire for a Lost Empire, (Uppsala: Uppsala University Press, 2014), pp. 275-86.

12. Martin Heidegger, 'The Thing', in Poetry, Language, Thought, trans. by Albert Hofstadter, (Harper and Row: New York, 1971), pp. 161-84

13. Heidegger, 'The Origin of the Work of Art', in Poetry, Language, Thought, trans. by Hofstadter, pp. 15-79, at p. 20.

14. Vladimir V. Nabokov, Transparent Things (New York: McGraw-Hill, 1972), p. 1. 15. Bill Brown, 'Thing Theory', Critical Inquiry, 28/1, Autumn 2001, pp. 1-22, at 13 . 